\begin{tabular}{|c|c|c|}
\hline & Int.J.Curr.Microbiol.App.Sci (2016) 5(12): 897-902 & \\
\hline & International Journal of Current Microbiology and Applied Sciences & \\
\hline & ISSN: 2319-7706 Volume 5 Number 12 (2016) pp. 897-902 & \\
\hline $\begin{array}{l}\text { EXCELLENT } \\
\text { PUBLISHERS }\end{array}$ & & (1) \\
\hline
\end{tabular}

Original Research Article

http://dx.doi.org/10.20546/ijcmas.2016.512.097

\title{
The Relationship between Staphylococcus aureus Infection and Some Asthma Markers As (IL - 4, IL - 10, IFN $\gamma$, IgE and FOXP3) in Asthmatic Patients
}

\author{
Hamadi Aabttan Al-Hilali* and Mohammed Mousa Atta \\ Department of Microbiology, College of Medicine/Al-Qadissyia University, Iraq \\ *Corresponding author
}

\begin{tabular}{|c|c|}
\hline & A B S T R A C T \\
\hline & \multirow{6}{*}{ 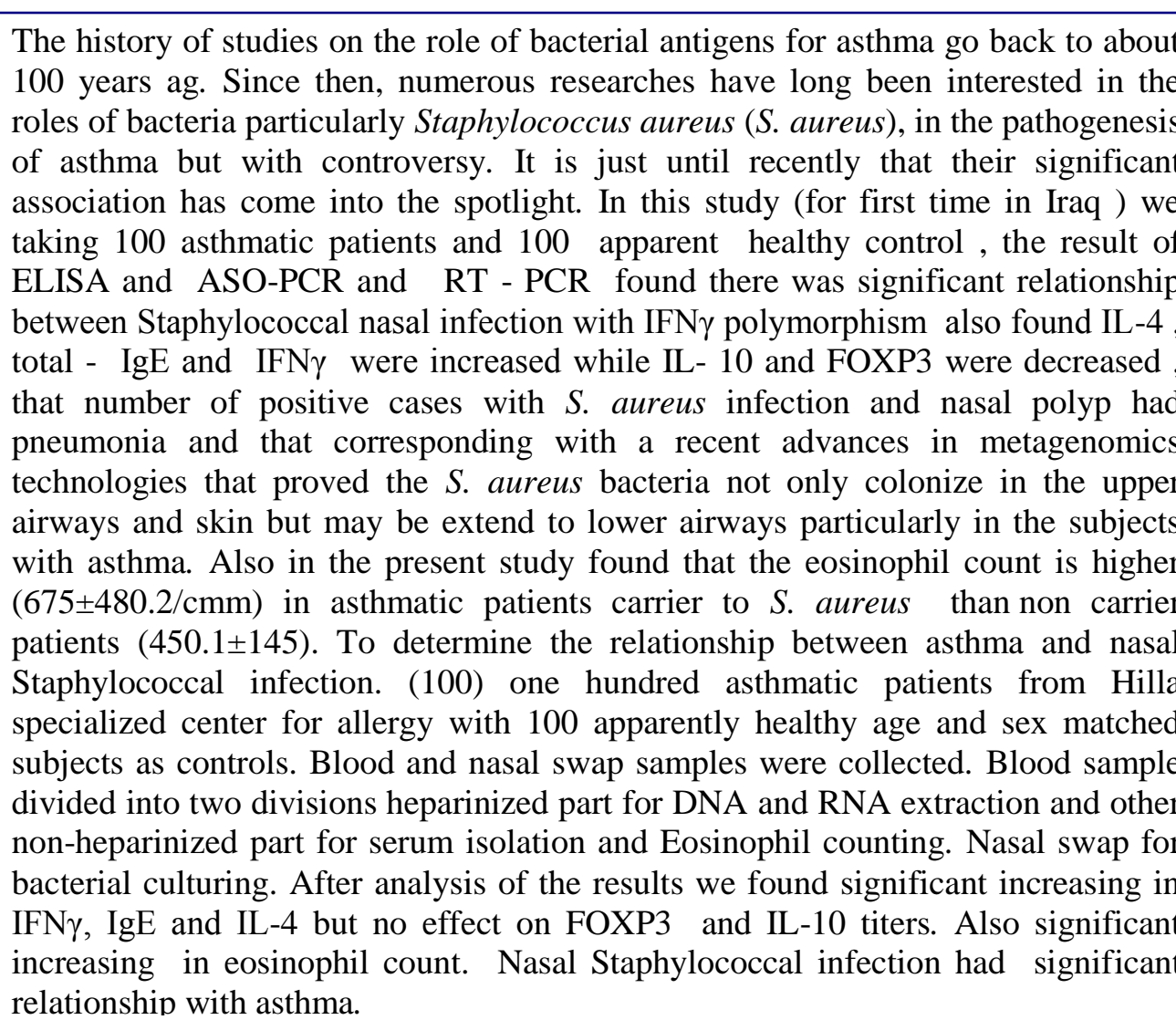 } \\
\hline Keywords & \\
\hline $\begin{array}{l}\text { Asthma. } \\
\text { Staphylococcus } \\
\text { aureus, } \\
\text { Nasal } \\
\text { Infection. }\end{array}$ & \\
\hline Article Info & \\
\hline $\begin{array}{l}\text { Accepted: } \\
\text { 20 November } 2016 \\
\text { Available Online: } \\
\text { 10 December } 2016\end{array}$ & \\
\hline & \\
\hline
\end{tabular}

\section{Introduction}

In ancient Greece, Galenus was the first physician to recognize the link between the nose and lung (Bachert et al., 2012). The link between upper and lower airways is now well established and has led to the concept of allergic rhinitis and its impact on asthma' (ARIA) (Anto et al., 2010). There is specific link between allergic rhinitis and 
asthma; as many as $50 \%$ of patients with allergic rhinitis have asthma, and up to $80 \%$ of asthma patients appear to suffer also from allergic rhinitis (Bachert et al., 2001). Allergic and nonallergic rhinitis are independent risk factors for development of asthma, and hypotheses have been developed to explain the link between allergic rhinitis and asthma (Sunyer et al., 1996). Rhinosinusitis (including nasal polyps) is clinically defined is an inflammation of the nose and the paranasal sinuses characterized by two or more symptoms including nasal blockage, anterior or postnasal drip, facial pain or pressure, and reduction in or loss of smell. Nasal polyps (NP) are whitish-gray mass-like lesions in the nose. They are almost always associated with chronic inflammation of the nose and paranasal sinuses, so called rhinosinusitis.

Histologically, nasal polyps show interstitial tissue edema, pseudocyst formation and collagen matrix disruption with abundant inflammatory cell infiltration (Gevaert et al., 2005). They usually protrude from the middle and superior meatus into the nasal cavity, causing rhinologic symptoms such as nasal blockage, anterior/posterior rhinorrhea, and smell disturbance. The etiology of nasal polyps is still unknown. Several hypotheses have been proposed, for instance the fungal hypothesis, the role of biofilm formation and the specific impact of superantigens of Staphylococcus aureus enterotoxins (SEs) as disease modifiers. The fungal biofilm can be considered as one possibility but the role of $S$. aureus is supported by more evidence and is more clinically relevant; biofilms may serve as reservoir for Staphylococcus aureus under specific circumstances. As NPs represent a chronic mostly eosinophilic inflammation, the first line therapy is topical glucocorticosteroid application, either as spray or drops (Chinn et al., 1998; Chinn et al., 1999; Hastan et al., 2011; Chinn et al., 1996). However, in cases of steroid unresponsiveness or recurrence of disease, surgery is the next choice. Furthermore, inflammation may expand to the lower airways and induce asthma; about one third of severe asthma sufferers have nasal polyps. Thus, there is an unmet need in terms of treatment options for severe cases of polyp disease with or without comorbidity. Recent trials propose new options such as doxycycline, anti-interleukin (IL)-5 and anti-immunoglobulin E (anti-IgE) (15). Staphylococcus aureus (S.aureus) is one of the most common human bacterial pathogens. However, it can multiply in a large proportion of the human population as a harmless colonizing organism.

The primary $S$. aureus colonization site in humans is the anterior nares. S. aureus produces enterotoxins, a family of proteins of different serological types but structurally and functionally related, and act as super antigens (Bachert et al., 2012). Staphylococcal enterotoxins can directly activate a large number of peripheral $\mathrm{T}-$ cells and cause more augmentation of Th2 response with subsequent aggravation of allergic reaction (Bachert et al., 2011). Other actions of Staphylococcal enterotoxins include polyclonal stimulation of IgE class switching, stimulation of local $\mathrm{IgE}$ synthesis in the airway mucosa, augmentation of allergen - specific $\operatorname{IgE}$ production and inhibition of $\mathrm{T}$ reg. cells (Hastan et al., 2011).

\section{Methods}

In a case control study, a total of 100 patients with asthma were referred to Hilla Allergy Specialized Center after they were suspected to have asthma according to their clinical manifestations, radiological changes, skin test and confirmed by allergen 
assay. Venous blood samples and nasal swap were collected from 100 patients suffering from asthma. The age of the patients are ranging from (10 - 75) years old including (40 males) and (60 females). Venous blood samples were taken from apparently healthy persons not suffering from any respiratory problems and have - ve family history to asthma, included 100 persons equal 50 males and 50 females with age range approximately matched to that of patients all control group confirmed diagnosed by radiological $X$ - ray and allergen assay who give - ve results.

Bacteriological study: after preparation of MSA and Blood agar, nasal swap was culture then identified by gram staining and confirmed by Vietk. ASO-PCR technique was performed for detection interferon Gamma Gene Polymorphism in the blood of asthma patients samples as well as in healthy blood samples as control groups. Methods were carried out according to method described by (Sarvari et al., 2011) Quantitative Reveres Transcription RealTime PCR technique was performed for estimation of relative gene expression analysis (FOXP3 and IL-10). This technique was done according to method described by manufactured company. Serological examination for titration of IFN $\gamma$, total $\mathrm{IgE}$, IL-4 by using Elabscience kits (Elisa kits).

\section{Results and Discussion}

As shown in table (1), there were no obvious or statistically significant differences in median Foxp3 fold change, IL10 fold change between Asthma cases with positive and negative Staph aureus culture result. Only the median Serum IL4 conc was significantly higher among Asthma cases with positive bacterial culture (676) compared to those with negative culture (599.5) and this corresponding with Refaat et al., (2008) who found significant increasing in IL-4 titter in case of Staph. positive asthmatic patients in study proved through which relationship between Staph. infection and severity of clinical signs in asthmatic patients. While Serum IFN gamma conc show significant increasing in this paragraph of study and this consistent with many different studies that proved the result as: Broderick et al., (2012); Song et al., (2014); Riechelmann et al., (2015); Sintobin et al., (2015) and Cui et al., (2015) and this well known because IFN gamma (Th1 cytokine) which chiefly responsible for immunity against infection. In the present study found that the eosinophil count is significantly higher $(675 \pm 480.2 / \mathrm{ml})$ in asthmatic patients carrier to $\mathrm{S}$. aureus than non carrier patients $(250.1 \pm 145)$ and correspond with other studies as Ensaf et al., (2015). Also IgE show statistically significant increasing in asthmatic patients with Staph.+ ve compared with healthy control and Staph. - ve asthmatic patients and this may be its enterotoxin which act as super antigen, these findings warrant further studies for elucidating mechanisms and for confirming their relationships in large scale population. There are many different studies proved that $\mathrm{S}$. aureus and its toxins have major role in asthma as following cited by (Jarvis et al., 2015).

Bachert et al., (2012), found enterotoxin IgE positivity was significantly greater in patients with severe asthma than in healthy control subjects so that they proved SE IgE antibodies but not $\operatorname{IgE}$ against inhalant allergens are risk factors for asthma severity and hypothesize that the presence of enterotoxin $\operatorname{IgE}$ in serum indicates the involvement of Staphylococcal super antigens in pathophysiology of patient with severe asthma.

Yang et al., (2005), proved that the asthma is closely related with sinusitis by taking 85 asthmatic patients they found 51 of 85 
patients with high serum anti staphylococcus enterotoxin B antibody before treatment obtained satisfactory results for both sinusitis and asthma.

Kowalski et al., (2011), observed that total
IgE had a strong correlation with specific IgE to SEs in serum from asthma patients that was independent of atopic status and these two factors significantly correlated with asthma severity markers.

Table.1 the difference in median of selected outcome measurements between Asthma cases with positive and negative Staph aureus bacterial culture

\begin{tabular}{|c|c|c|c|}
\hline & \multicolumn{2}{|c|}{$\begin{array}{l}\text { Staph. aureus } \\
\end{array}$} & \multirow[b]{2}{*}{$\mathbf{P}$} \\
\hline & Negative & Positive & \\
\hline Foxp3 fold change & & & $0.1[\mathrm{NS}]$ \\
\hline Range & (2.11 to 35.13 ) & (1.73 to 55.02$)$ & \\
\hline Median & 5.28 & 7.685 & \\
\hline Inter-quartile range & (3.42 to 9.97$)$ & (4.03 to 11.965$)$ & \\
\hline $\mathrm{N}$ & 36 & 64 & \\
\hline Mean Rank= & 44.1 & 54.1 & \\
\hline IL10 fold change & & & $0.58[\mathrm{NS}]$ \\
\hline Range & (2.8 to 35.13$)$ & (2.12 to 65.89$)$ & \\
\hline Median & 7.845 & 7.905 & \\
\hline Inter-quartile range & (5.965 to 12.495$)$ & (4.76 to 11.525$)$ & \\
\hline $\mathrm{N}$ & 36 & 64 & \\
\hline Mean Rank= & 52.6 & 49.3 & \\
\hline Serum IgE conc & & & 0.005 \\
\hline Range & (3.8 to 29.8 ) & (83.8 to 215.8 ) & \\
\hline Median & 24.65 & 28.6 & \\
\hline Inter-quartile range & (14.6 to 38.15$)$ & (17.7 to 40.05$)$ & \\
\hline $\mathrm{N}$ & 26 & 64 & \\
\hline Mean Rank= & 47.2 & 52.4 & \\
\hline Serum IFN gamma conc & & & 0.002 \\
\hline Range & (275.5 to 402$)$ & (874.5 to 1119$)$ & \\
\hline Median & 265 & 464 & \\
\hline Inter-quartile range & ( 353.25 to 645 ) & (347.25 to 709.25$)$ & \\
\hline $\mathrm{N}$ & 36 & 64 & \\
\hline Mean Rank= & 50.6 & 50.5 & \\
\hline Serum IL4 conc & & & 0.005 \\
\hline Range & (305 to 1080 ) & (304 to 2390 ) & \\
\hline Median & 599.5 & 676 & \\
\hline Inter-quartile range & $(458.5$ to 670.5$)$ & (573.5 to 739 ) & \\
\hline $\mathrm{N}$ & 36 & 64 & \\
\hline Mean Rank= & 39.7 & 56.6 & \\
\hline
\end{tabular}


4. Xin Yan et al., (2015), found positive rate and level of SEB specific IgE significantly higher in the serum from Chinese patients with Chronic Rhinosinusitis without nasal polyp than that from healthy control so, the positive rate and level of SEB - specific IgE in Chronic Rhinosinusitis with nasal polyp showed an increasing trend but didn't reach significance.

5. Lara et al., (2010), proved that the S. aureus is correlated with the development of persistent severe inflammatory diseases of the upper airway including Chronic Rhino sinusitis with nasal polyp.

6. Tomassen et al., (2013), in first large scale population - based epidemiological study to demonstrate the sensitization to S. aureus enterotoxins in European volunteers, they are demonstrated that $\operatorname{IgE}$ sensitization to $\mathrm{SE}$ is common in Europe, may occur in the absence of sensitization to other allergens (aeroallergens such as house dust mite), probably reflecting a different pathophysiologic basis, this effect may be mediated through its association with strongly increased total $\mathrm{IgE}$ concentration via polyclonal super antigen action of enterotoxins.

7. The effects of $S$. aureus nasal carriage on nasal cytokines environment was noticed by Riechelmann et al., (2015) and Refaat et al., (2008) who found that S. aureus nasal carriage in allergic rhinitis patients was associated with high levels of nasal IL-4 and IL-13 (Th2 cytokines) and low level of IFN $\gamma$ (Th1 cytokines) and its associated with high nasal IgE level suggesting that nasal S. aureus can augment Th2 bias and promote local $\mathrm{IgE}$ production thus can actively modulate the allergic reaction in affected tissues.
8. Ensaf et al., (2015) found significant positive correlation between SEB - specific IgE level in patients and markers of severity of allergic reaction including blood eosinophilia, ECP and total IgE levels, So that, they suggest that nasal carriage of enterotoxin producing $\mathrm{S}$. aureus has a potential role in the development and severity of allergic airway diseases.

(Conclusion the presence of Staph aureus had no effect on Foxp3 fold change and IL10 fold change but there was significant increasing in Serum IgE conc, Serum IFN gamma conc. and Serum IL4 conc.) Also found in this study also found all asthmatic patients (+ve) with nasal Staphylococcal infection had nasal polyp, and that is already because of the Staph. aureus is main causative agent for nasal polyp (Bachert $e t$ al., 2012) also there was highly significant relationship between Staph. aureus infection and IFN $\gamma$ polymorphism $\mathrm{A} / \mathrm{T}$ at 874 position in case of asthmatic patients (asthmatic patients +ve with Staph. aureus infection were 64 patients and from those 52 patients $(81.25 \%)$ had IFN $\gamma$ polymorphism (AT, TT genotype) so that, this may be good indicator or evidence suggesting that the Staph. aureus super antigens is the main cause or chiefly predisposing factor for IFN $\gamma$ polymorphism).

\section{References}

Anto, J.M., Sunyer, J., Basagana, X., Garcia Esteban, R., Cerveri, I., de Marco, R. et al. 2010. Risk factors of new-onset asthma in adults: a population-based international cohort study. Allergy, 65: 1021-1030.

Bachert, C., Gevaert, P., Holtappels, G., Johansson, S.G., van Cauwenberge, P. 2001. Total and specific IgE in nasal polyps is related to local eosinophilic 
inflammation. J. Allergy Clin. Immunol., 107: 607-614.

Bachert, C., Gevaert, P., Howarth, P., Holtappels, G., van Cauwenberge, P., Johansson, S.G. 2003. IgE to Staphylococcus aureus enterotoxins in serum is related to severity of asthma. $J$. Allergy Clin. Immunol., 111: 1131-1132.

Bachert, C., van Steen, K., Zhang, N., Holtappels, G., Cattaert, T., Maus, B. et al. 2012. Specific IgE against Staphylococcus aureus enterotoxins: an independent risk factor for asthma. $J$. Allergy Clin. Immunol., 130: 376-381.

Chinn, S., Burney, P., Sunyer, J., Jarvis, D., Luczynska, C. 1999. Sensitization to individual allergens and bronchial responsiveness in the ECRHS. European Community Respiratory Health Survey. Eur. Respir. J., 14: 876- 884.

Chinn, S., Jarvis, D., Luczynska, C., Burney, P. 1998. Individual allergens as risk factors for bronchial responsiveness in young adults. Thorax, 53: 662-667.

Chinn, S., Jarvis, D., Luczynska, C.M., Lai, E., Burney, P.G. 1996. Measuring atopy in a multi-centre epidemiological study. Eur. J. Epidemiol., 12: 155-162.

Gevaert, P., Holtappels, G., Johansson, S.G., Cuvelier, C., Cauwenberge, P., Bachert, C. 2005. Organization of secondary lymphoid tissue and local IgE formation to Staphylococcus aureus enterotoxins in nasal polyp tissue. Allergy, 60: 71-79.

Hastan, D., Fokkens, W.J., Bachert, C., Newson, R.B., Bislimovska, J., Bockelbrink, A. et al. 2011. Chronic rhinosinusitis in Europe - an underestimated disease. A GA2LEN study. Allergy, 66: 1216-1223.

Heinzerling, L.M., Burbach, G.J., Edenharter, G., Bachert, C., Bindslev-Jensen, C.,
Bonini, S. et al. 2009. GA2LEN skin test study I: GA2LEN harmonization of skin prick testing: novel sensitization patterns for inhalant allergens in Europe. Allergy, 64: $1498-1506$.

Hollams, E.M., Hales, B.J., Bachert, C., Huvenne, W., Parsons, F., de Klerk, N.H. et al. 2010. Th2-associated immunity to bacteria in teenagers and susceptibility to asthma. Eur. Respir. J., 36: 509-516.

Jarvis, D., Newson, R., Lotvall, J., Hastan, D., Tomassen, P., Keil, T. et al. 2015. Asthma in adults and its association with chronic rhinosinusitis: the GA2LEN survey in Europe. Allergy, 67: 91-98.

Kowalski, M.L., Cieslak, M., Perez-Novo, C.A., Makowska, J.S., Bachert, C. 2011. Clinical and immunological determinants of severe/refractory asthma (SRA): association with Staphylococcal superantigen-specific IgE antibodies. Allergy, 66: 32-38.

Leung, D.Y., Harbeck, R., Bina, P., Reiser, R.F., Yang, E., Norris, D.A. et al. 1993. Presence of IgE antibodies to staphylococcal exotoxins on the skin of patients with atopic dermatitis. Evidence for a new group of allergens. J. Clin. Invest., 92: 1374-1380.

Sunyer, J., Anto, J.M., Castellsague, J., Soriano, J.B., Roca, J. 1996. Total serum IgE is associated with asthma independently of specific IgE levels. The Spanish Group of the European Study of Asthma. Eur. Respir. J., 9: 1880- 1884.

Van Zele, T., Gevaert, P., Watelet, J.B., Claeys, G., Holtappels, G., Claeys, C. et al. 2004. Staphylococcus aureus colonization and $\mathrm{IgE}$ antibody formation to enterotoxins is increased in nasal polyposis. J. Allergy Clin. Immunol., 114: 981-983.

\section{How to cite this article:}

Hamadi Aabttan Al-Hilali and Mohammed Mousa Atta. 2016. The Relationship between Staphylococcus aureus Infection and Some Asthma Markers As (IL - 4, IL - 10, IFN $\gamma, \operatorname{IgE}$ and FOXP3) in Asthmatic Patients. Int.J.Curr.Microbiol.App.Sci. 5(12): 897-902. doi: http://dx.doi.org/10.20546/ijcmas.2016.512.097 